\title{
Complex Genetic Disorders and Intellectual Property Rights
}

\author{
Principal Investigator: Lori B. Andrews
}

September 1, 2002 - August 31, 2005

Final Report

Illinois Institute of Technology, 3300 S. Federal, Chicago, IL 60616

DOE Award: ER63460-1020250-0008375

Patents awarded for human genetic material have raised domestic and international controversies and are currently being challenged in courts, legislatures, and the public arena. Some critics argue that genes should not be patentable because they are inherently products of nature, while others focus on the impact of gene patents on health care and research. Challenges to gene patent policies have been initiated by a variety of interested parties: people from whom the patented genes were isolated, researchers who wish to undertake genetic epidemiology or develop gene therapies, clinicians and health plan operators who allege that they cannot afford the licensing fees for genetic tests, and policymakers who want to ensure that the patent system actually meets its goal by encouraging invention. The issue is prominent around the world. For example, during the course of the project, the European Patent Office revoked a Myriad Genetics’ BRCA1 breast cancer gene patent, and the Australian Law Reform Commission issued a 795-page report entitled Gene Patents and Human Health.

This project analyzed challenges to existing gene patent policies and assessed whether those challenges are adequately responsive to the problems that gene patents appear to be causing with respect to health care and research. The research team collected and analyzed information on all U.S. and international challenges to gene patents; existing and proposed U.S. and international laws, regulations, and treaties relevant to the issue of gene patents; and policy proposals (such as proposals for gene patent pools and proposals to allow patients to be considered co-inventors on gene patents). The team also assessed the impacts of the existing and proposed patent regimes on genetic research and the development of diagnostic and treatment technologies for complex genetic disorders.

This project also undertook a rigorous claim-by-claim analysis of gene patents that have actually been granted. This was an assessment that had never been undertaken before by any researcher. This aspect of the study was unique because it asked the question, assuming human gene sequences are patentable, do the claims contained within human gene patents issued by the United States Patent \& Trademark Office (USPTO) meet the statutory requirements for patentability under U.S. patent law? To answer this question, the research team analyzed a variety of human gene patents implicated in nine genetic diseases awarded by the USPTO in order to assess whether they comply with existing patent law as codified in federal provisions. (35 U.S.C. §101 et seq.) Applying U.S. patent law on a claim-by-claim basis, the research team examined actual claims over human genetic material present in issued patents and identified and 
categorized potential problems. These findings are the conclusions of project personnel and are not necessarily predictive of eventual validity determinations by the courts or the USPTO.

After a patent application is filed with the USPTO, the validity is assessed on a claim-byclaim basis by one or two USPTO patent examiners. Based on the examiner(s) findings, each patent claim is either granted or rejected. The project researchers found that despite changes to the law that had made the utility requirements more stringent, gene patents continue to be awarded that arguably fail to comply with existing patent law.

The research team analyzed 1167 claims in 74 gene patents and found that $38 \%$ of the claims granted by the USPTO were problematic. Some claims had multiple problems, resulting in 677 cumulative problems within the 448 problematic claims. Of the 677 total problems identified, written description and enablement/utility problems were the most frequent. Many patents claimed far more than what the inventor actually discovered. Some applicants took advantage of the redundancy of the genetic code by, for example, claiming the sequence of a protein within a patent and then also asserting rights over all of the DNA sequences that encode for that protein without describing those DNA sequences. For example, one patent claimed "(a)n isolated nucleic acid molecule other than a naturally occurring chromosome comprising a sequence which encodes a mammalian ASTH1 protein.”

Other problematic claims were drafted where the applicant knew only a small part of the desired gene sequence but asserted claims over a larger segment. One such claim in an existing patent covered "analyzing human chromosome 9 of the subject and detecting the presence of a polymorphism located between HXB and D9S109 inclusive and linked to the gene associated with familial dysautonomia and wherein the presence of the polymorphism is indicative of carriers of a gene associated with familial dysautonomia.” This claim encompassed 12.5 million base pairs (Mbp); meaning that any subsequent researcher or doctor would need to request a license from the patent holder in order to look at any polymorphism located anywhere in that $12.5 \mathrm{Mbp}$.

Other common problems related to the utility of the invention. Some gene patents claimed a method for diagnosis and/or prediction of various genetic diseases, but did not provide an explanation of how to use the gene/polymorphism to identify all of the diseases listed within the claim. For example, one patent claimed a method for "diagnosis and prediction of an inflammatory condition of respiratory tissues that is associated with tissue accumulation of eosinophils, wherein the method comprises the step of identifying a nucleic acid sequence exhibiting a polymorphism in an eotaxin gene, whereby that polymorphism comprises a substation of adenine for guanine 67 base pairs following the ATG initiation codon of the gene, whereby counting is initiated at the A in that codon, and wherein the inflammatory condition is thereby diagnosed or predicted." Except for asthma, the patent provided no indication of how the claimed polymorphism was to be used to identify the numerous other inflammatory conditions named within the patent and covered by the claim.

Another troubling issue arose where a claim was drafted disclosing only a correlation between two things, often the presence of an isoform or mutation and some multigenic disorder or a disorder having a genetic component. In some cases, the patent holder did not describe how the correlation could be used to predict the disease. One such patent claimed a "method of 
detecting if a subject is at increased risk of developing late onset Alzheimer's disease (AD) comprising directly or indirectly: detecting the presence or absence of an apolipoprotein E type 4 isoform (ApoE4) in the subject." The claim failed to account for other factors that relate to a person developing Alzheimer's disease and did not indicate the specific relationship between the presence of ApoE4 and the increased risk, but merely provided that there is a correlation. In fact, even where a patient does not have the ApoE4 isoform, he or she could still develop the disease and those with the ApoE4 isoform might never develop the disease. The "indirect" detection method was also vague enough that it could include any diagnosis based on external factors as well, such as memory loss (a diagnostic method which was not invented by the patent applicant).

The research team also identified patent claims that suffered from one or more problems but were saved from being classified as problematic due to the drafting language. For example, one claim covered, "[t]he method of claim 1, 2, or 3, wherein the method further comprises amplifying the sequence-altered PAH DNA by use of the polymerase chain reaction (PCR)." Two of the three referenced claims were problematic. Claim 1 had written description, enablement/utility, and novelty/nonobviousness problems and claim 3 had enablement/utility problems. Project personnel concluded that this claim was not problematic because it referenced claim 2, which contained no problems with any of the established categories. This language may create a chilling effect on other inventors who want to use methods listed in the patent, but do not realize that the patent was open to challenge as not validly covering those methods.

In addition to analyzing the claims themselves, the research team also analyzed the patents to determine whether there were differences between university assigned gene patents and those held by non-universities, such as corporations or individuals. The project divided the patents into two general categories: (1) a university patent, which is a patent that lists the university itself or an internal school thereof as at least one of the assignees; and (2) a nonuniversity patent, which is a patent that lists any other institution or person. A hospital affiliated with a university was considered a non-university assignee. Examples of university assignees include Duke University, the Trustees of Columbia University, and Ramot University in Israel.

Approximately two-thirds of the patents analyzed had a non-university assignee. BRCA1 and BRCA2 had $62 \%$ of its patents assigned to non-university entities. Half of the patents analyzed related to schizophrenia had a university assignee. The number of university patents outnumbered the number of non-university patents in Alzheimer's and A-T. However, non-university assignees had a significantly larger percentage of the total patent claims, at approximately 77\%. Perhaps the investment risk in undertaking research on the technology was the driving factor to these haphazard ratios, in that it appeared that a non-university entity was more likely to be the assignee when the potential market was more lucrative.

University and non-university patents each had approximately the same percentage of problematic patents, but had different percentages of problematic claims. The results showed that $71 \%$ of non-university gene patents had at least one claim that was problematic and $74 \%$ of non-university gene patents had at least one claim that was problematic. The similarity in these percentages of problematic patents suggests that both university and non-university entities generally have the same strategy in obtaining a patent, that is, to include at least one broad claim in each patent regardless of whether that broad claim may be problematic or not. 
However, university-assigned gene patents differed from non-university gene patents in the number of claims they included. University patents averaged just over 11 claims per patent and non-university patents averaged almost 18 claims per patent. The claims in universityassigned patents were substantially more likely to be problematic. Fifty-nine percent of university claims were problematic compared to 32\% of non-university claims.

The claim problems differed in type, too. University patents had the following distribution for problems: 43\% written description, 36\% enablement/utility, 10\% novelty/nonobviousness, and $11 \%$ definiteness. Non-university patents had fewer written description and novelty problems, but more enablement/utility and definiteness problems compared to the university patents: $34 \%$ written description, $46 \%$ enablement/utility, $5 \%$ novelty, and $15 \%$ definiteness.

Based on the findings, the research team proposed a variety of actions to lessen the negative impact of gene patents on healthcare and research. More rigorous training of patent examiners would help ameliorate some of the identified problems, particularly training about the biological and genetic aspects of claims within gene patent applications. There are also a number of potential legislative and judicial solutions, including an amendment to federal patent law to allow a research and health exemption for gene patents or a court decision that categorically rejects gene patents or rejects a particular form of claiming a gene-based invention. In terms of policy options, the United States could also impose compulsory licensing of gene patents or independent regulation through a federal agency.

\section{Products:}

Articles:

Jordan Paradise, Lori Andrews, and Timothy Holbrook, "Problems in Patenting Human Genes," 308 Science 1869 (2005).

Jordan Paradise, Lori Andrews, and Timothy Holbrook, "Patents on Human Genes: An Analysis of Scope and Claims,” 307 Science 1566-1567 (2005).

Lori B. Andrews, "Harnessing the Benefits of Biobanks,” 33 J. Law, Med. \& Ethics 22-30 (2005).

Lori B. Andrews and Jordan Paradise, "Gene Patents: The Need for Bioethics Scrutiny and Legal Change,” 5 Yale J. Health Pol’y L. \& Ethics 403-412 (2005).

Lori Andrews, “Bioethics: The Beginning and End of Life,” Illinois Issues 16-21 (March 2005).

Lori Andrews, "Havasupai Tribe Sues Genetic Researchers," 4 Law and Bioethics Report 10-11 (Winter 2004), reprinted in 31 Privacy Journal 5-6 (April 2005). 
Lori Andrews, “The Body as Property in the Biotech Era," chapter in Identity in a Digital Age, (Berlin, Germany: Bundes Druckerei 2004).

Lori Andrews and Jordan Paradise, "Gene Patents and Bioethics," contribution to UNESCO's Extraordinary Session of the International Bioethics Committee, Paris, April 27-29, 2004.

Jordan Paradise, "European Opposition to Exclusive Control Over Predictive Breast Cancer Testing and the Inherent Implications for U.S. Patent Law and Public Policy: A Case Study of the Myriad Genetics' BRCA Patent Controversy," 59 Food \& Drug L.J. 133-154 (2004).

Lori Andrews, “Is it Ethical to Patent People?” Chicago Tribune, November 9, 2003, at 9.

Presentations by Lori Andrews:

"Shared Patenting Experiences: the Roles of Patients," PropEur Workshop, Bilbao, Spain, December 2005.

"The Impact of Gene Patents on the Delivery of Health Care Services," March of Dimes Bioethics Committee, White Plains, NY, October 2005.

"People as Products: Gene Patents, Tissue Markets, and the Ethics of Biotech,” Wheaton College, Wheaton, IL, March 2005.

"The Gene Patent Paradox: Challenges for Physicians and Attorneys," American College of Legal Medicine, San Diego, CA, March 2005.

"Life Science Art: A New Tool for Assessing Biotechnology," School of the Art Institute, Chicago, IL, February 2005.

"Science, Law, and the Arts: Perspectives on Gene Patents," Amherst College, Amherst, MA, February 2005.

"Who Owns Genes? Implications of Gene Patents for Physicians and Hospitals," Cedars-Sinai Medical Center, Los Angeles, CA, January 2005.

"Gene Patents, Pharmacogenomics, and Appropriate Health Care,” University of Chicago, Chicago, IL, January 2005.

"Legal Issues in the Posthuman Era," Technosapiens Conference, Washington, DC, October 2004.

"The Role of the Institute on Biotechnology and the Human Future," U.S. Capitol Briefing on Gene Patents, Washington DC, October 2004.

“Don’t It Make My Brown Eyes Blue?” The Chicago Network, Chicago, IL, September 2004. 
"The Body as Property: The Ethics of Research on and Commercialization of Patient Tissue Samples,” University of Illinois at Chicago, Department of Pathology, Chicago, IL, April 2004.

“The Body as Property: Gene Patents and Health Care Policy” Suffolk University Law School, Health Law and Policy Forum, Boston, MA, March 2004.

“Controversies in Public Policy,” Connecticut Department of Public Health, March 2004.

“Who Owns Genes?” Intensive Ethics Education Course, Mayo Clinic, Rochester, MN, February 2004.

"An Overview of the Legal Issues Posed by Human Genetics,” ABA Meeting, Raleigh, N.C., October 2003.

“The Impact of Gene Patents On the Delivery of Health Care Services,” Robert Wood Johnson Foundation, Investigator Awards in Health Policy Research, Tenth Anniversary Meeting, Vale, CO, October 2003.

"Policy Alternatives for Gene Patents," American Association for the Advancement of Science, Washington, DC, June 2003.

“Gene Patenting,” Northwestern University, Chicago, IL, April 2003.

"People as Products: Gene Patents, Tissue Markets, and the Ethics of Biotech,” Emerson Lecture, Duke University, Durham, N.C., April 2003.

“The Patent Paradigm: Implication for Biotech Companies,” Santa Clara, CA, Affymetrix, April 2003.

"People as Products: Gene Patents, Tissue Markets, and the Ethics of Biotech,” Loyola University Chicago Stritch School of Medicine, Chicago, IL, April 2003.

"Brave New Laws: From Gene Patents to Designer Babies,” Yale Law School Alumni Talk, Chicago, IL, March 2003.

Presentations by Tim Holbrook:

"Curing Heterosexuality? Moral Signals and the Potential for Expressive Impacts in Patent Law,” Loyola University Chicago School of Law, IP Brown Bag Lunch Series, Chicago, IL, March 2005.

Commentator on "Constitutionalizing Patents" by Craig Allen Nard and Andrew P. Morriss, Where IP Meets IT: Technology and the Law Symposium, University of Pittsburgh School of Law, Pittsburgh, PA, March 2005. 
“The Calm Before the Storm—A Quiet Year in Patent Law . . or Not?,” University of Akron Law School, the Richard C. Sughrue Symposium on Intellectual Property Law and Policy, Akron, OH, March 2005.

"Curing Heterosexuality? Moral Signals and the Potential for Expressive Impacts in Patent Law,” Colloquium: Reenvisioning Law, University of Houston Law Center, Houston, TX, January 2005.

"Procedural versus Substantive Formalism in Claim Construction,” presented at the Tenth Annual Lewis \& Clark Law School Fall Business Law Forum, entitled "Markman v. Westview Instruments: Lessons from a Decade of Experience,” Portland, OR, October 2004.

"Does the Patent System Need Fixing? Panel Discussion on the Federal Trade Commission Report 'To Promote Innovation: The Proper Balance of Competition and Patent Law and Policy,” Panel Member, Federal Bar Association, Chicago, IL, September 2004.

"Curing Heterosexuality? Moral Signals and the Potential for Expressive Impacts in Patent Law,” Faculty Workshop, Washington University School of Law, St. Louis, MO, April 2004.

"Curing Heterosexuality? Moral Signals and the Potential for Expressive Impacts in Patent Law," University of San Francisco, J. Thomas McCarthy Institute for Intellectual Property and Technology Law, San Francisco, CA, Wednesday, March 2004.

Presentations by Jordan Paradise:

“Genetic Modifications: Ethical, Legal and Social Implications,” Reproductive Technology Seminar, Chicago-Kent College of Law, Chicago, IL, April 2005.

“Gene Patents and Intellectual Property,” University of Minnesota Law School, Minneapolis, MN, January 2005.

\section{Most recent notes concerning the project:}

None

\section{Other Project Information Sources:}

\section{Project URL:}

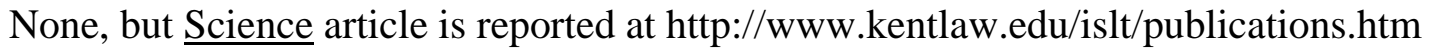

\section{Related URL at institution:}

None 